DOI https://doi.org/10.18551/rjoas.2021-03.13

\title{
STUDY OF WORKPLACE POLITICS
}

\author{
Aransyah Muhammad Fikry*, Hetami Adietya Arie \\ University of Mulawarman, Samarinda, Indonesia \\ E-mail: fikryaransyah@fisip.unmul.ac.id
}

\begin{abstract}
Politics is an organizational activity associated with power and personal status. Politics that occur on the spot is becoming increasingly common among workers. Of course, many factors influence the emergence of politics in the workplace. This research is a descriptive study with a qualitative approach. In this research, the method used is to conduct literature studies by analyzing various books, research journals, and other scientific references that discuss workplace politics that have been published from 1989-2018. Several indicators are formed through the literature review, and there are relationships with political behavior. The five indicators are unclear objectives, budget allocation, decision making, salary and promotion, power, and job dissatisfaction. Job dissatisfaction impacts workplace politics and is not the same as the five factors that influence workplace politics.
\end{abstract}

\section{KEY WORDS}

Politics, workplace, salary, power.

Politics is a part of our life, and it is difficult to avoid it. Humans tend to behave politically to maximize their benefits. According to KBBI, politics means government activity, consisting of parties' involvement and relations between countries. Apart from that, it is also an organizational activity to be associated with power and personal status. There are two types of politics, namely organizational politics and government politics. In this research, this article's primary focus is organizational politics, especially workplace politics or office politics.

"Organizational politics is a social influence process in which behavior is strategically designed to maximize short- or long-term self-interest, consistent with or at the expense of the interests of others" (Miller et al., 2008). Olorunleke's (2015) research suggests several factors lead to workplace politics: high hierarchy, uncertain environment, the ambiguity of goals, and others (Olorunleke, 2015). Organizations are filled with different types of people, resources, and goals. Each person may have a different opinion when it comes to allocating their resources. Therefore, every organizational leader tries to use political tactics to influence the allocation of resources. What is most commonly seen in every organization is budget allocation. In uncertain environments, such as mergers and acquisitions or management changes, employees will try to protect their jobs and build coalitions.

Olorunleke (2015) argues that workplace politics cannot be avoided and does not always mean it is bad. Workplace politics can help influence organizational decision-making processes. Also, leaders try to influence their subordinates to support their decision-making. These influences can help speed up the decision-making process as well as work efficiency. Besides, it can focus employees in theorganization (Sonaike, 2013). Kinicki (2008) states that there are many units in the organization, and each unit has its function. Leaders need to know about workplace politics to coordinate each unit. Politics acts as a lubricant to smooth the process. According to Khan and Hussain (2014), there is a political need to help teams succeed. However, too much politics can also destroy team harmony.

Politics must be used positively, not to harm others. The study of Khan and Hussain (2014) suggests that one of the best ways to stay at work is to join strong groups. If one of the members is working overtime every day, this will cause their colleague to boycott that member. Colleagues may think that they are trying to please their boss by working hard. Also, humans tend to maximize their interests; this has led to the emergence of political behavior in the workplace. 
Workplace politics can negatively impact employees, and leaders can be selfish because they will try to pursue their interests. Examples of self-interest are promotions and salaries (Olorunleke, 2015). Besides, workplace politics also cause employees to become stressed and quit their jobs. Research by Nasurdin, Ahmad, and Razalli (2014) shows that organizational politics is one source that causes employees to experience stress. Workplace politics affects employees to become emotionally unstable, tense, and frustrated. Employees will be exhausted because their efforts do not match the rewards they receive.

Buchanan (2008) argues that the subject of workplace politics is still under-explored. Research by Olson, Bao, and Parayitam (2014) states that most researchers focus on two areas: the perception of employees' organizational politics and political behavior (Olson, Bao, \& Parayitam, 2014). Research Vigoda-Gadot \& Drory (2006) and Cacciattolo (2013) also suggest further research on employee behavior during political situations and their reactions. Furthermore, to understand employees' political behavior, it is necessary to understand the factors that cause the political situation (Cacciattolo, 2013). Many researchers suggest that there are still many areas in workplace politics. Therefore, workplace politics has been selected in the study to investigate further the factors that lead to workplace politics.

Daud, Isa, Nor, \& Zainol (2013) suggest that workplace politics is a significant issue in today's business world because employees use this influence to maximize their profits. Employees who have much time for workplace politics might pay less attention to their work. Workplace politics can result in low organizational efficiency that affects organizational performance. Furthermore, workplace politics also influence job dissatisfaction (Ferris \& Kacmar, 1992). Job satisfaction among employees is vital to maintain organizational performance. Therefore, this study also examines the influence of workplace politics on employee job satisfaction.

It is essential to understand the factors that influence workplace politics as this will help workers mature and increase their interactions with others. Workplace politics are a part of life and hard to avoid. Most people view politics as unfavorable. However, workplace politics have contributed to the organization. Workplace politics can help employees to work towards achieving organizational goals. Sometimes, it is challenging to get each unit to coordinate without politics. Besides, workers will understand the purpose behind political behavior. This study can help them understand their colleagues and increase the interaction between them. Besides, workers have some ideas about the political system around them and learn how to manage it.

\section{METHODS OF RESEARCH}

The research method used is literature study research. A total of 25 published studies from 1989-2018 on workplace politics have been identified and reviewed. This data used in workplace politics also discusses the six indicators of workplace politics: unclear objectives, budget allocation, decision making, salaries and promotions, power, and job dissatisfaction. Then the authors used traditional narratives literature review on workplace politics and focused on empirical papers.

\section{RESULTS AND DISCUSSION}

Workplace politics. Organizational politics is a social influence process in which behavior is strategically designed to maximize short-term or long-term self-interest, consistent with or at the expense of others' interests (Miller et al., 2008). Ferris's research (1989) defines politics as workplace behavior to increase employee self-benefit (Nasurdin, Ahmad \& Razalli, 2014). One researcher argues that activities will maximize employee benefit and influence people who have the authority to give awards (Cropanzano, 1989; Nasurdin, Ahmad, \& Razalli, 2014). There are three categories of factors that influence organizational politics. The first category is organizational influence or organizational structure; the second category is work and colleagues; The third category is employee characteristics (Ferris \& Kacmar, 1992). 
Furthermore, workplace politics also has several consequences: employee resignation from the organization or employee absence (Ferris, Russ, \& Fandt, 1989; Ferris \& Kacmar, 1992). If employees continue to stay in the organization, they may become involved in workplace politics (Ferris, Russ, \& Fandt, 1989; Ferris \& Kacmar, 1992). Below, we have explored three dimensions: General Political Behavior, Going along to Get Ahead, and Salaries and Promotions.

General Political Behavior occurs when rules and regulations are not clear. Individual employees will begin to develop their own rules, and these rules often benefit the rule maker (Kacmar \& Carlson, 1997). The decision-making process will be affected if there are no clear guidelines and targets. Employees will begin to use political tactics to influence decisionmaking. The scarce organizational resources will also increase political behavior in the organization.

Furthermore, previous research also states that resources' attractiveness will also influence organizational, political behavior (Kacmar \& Carlson, 1997). An example has been raised: vacation tickets compared to salaries and promotions. Employees want to get payroll and promotions rather than hosting holiday events. Employees who do not like vacations will tend to relax a little in their work. However, employees who enjoy the holiday event will work harder to get it.

Going along to Get Ahead is where employees do not want to come into conflict with coworkers. So they choose to mingle with fellow employees regardless of the coalition. The researcher saw this as a political act, even though there was no coalition of employees. The coalition can accept these employees because they do not harm the group (Kacmar \& Carlson, 1997).

The final dimensions to be discussed are salary and promotion. Every organization has a salary and promotion policy to reward its employees (Kacmar \& Carlson, 1997). If the boss always rewards subordinates who always support him, this behavior is likely to be imitated by others. These employees will always support their boss's decision to increase favoritism. According to Robbins and Judge (2013), political behavior is not included in job requirements; however, it can influence the process. Sometimes, it also takes power to influence the process. Organizational leaders use their power to influence organizational processes, goals, and decision-making.

Political behavior can be in the form of disseminating information on private organizations to outside parties, withholding some information without telling others during meetings, forming coalitions, and others (Robbins \& Judge, 2013). Political behavior can be considered ethical if it does not directly harm others. In other words, if the political behavior is directly detrimental to others, then it can be considered unethical behavior. Omisore \& Nweke (2014) suggest the need to understand bargaining, the influence of power, and coalitions before examining political behavior.

Three groups can easily create political behavior (Omisore \& Nweke, 2014): the working group, interest group, and coalition. Workgroup means the employees are from the same unit. There are many workgroups in an organization, such as accounting units, marketing units, and others. Interest groups are groups that have the same interests. They have the same goal, and they depend on each other. For a coalition, they work together to achieve goals. Employees are involved in politics because of power, organizational resources, and self-benefits (Ene, 2014).

From the literature review above regarding workplace politics, six indicators have been established. The six factors are the ambiguity of objectives, budget allocation, decision making, salary and promotion, power, and job dissatisfaction with workplace politics. Besides, five factors have a direct influence on workplace politics except for job dissatisfaction. Work dissatisfaction is a result of workplace politics.

Ambiguity of goals. The first factor for describing workplace politics is the ambiguity of goals. Research by Ferris et al. (1989) argued that environmental ambiguity would support political behavior. Organizations that do not have clear rules will increase political behavior. Organizational goals must be significant in formulating the organization strategically and 
providing direction to employees. Environmental uncertainty can take the form of mergers, acquisitions, and streamlining of organizational operations (Somoye, 2016).

Additionally, the employee is unsure of the new management direction. Olorunleke's (2015) research shows that employees will be less involved in workplace politics if they have shared values or goals. Somoye's research (2016) suggests that complex goals can improve political behavior, especially technology. An environment of uncertainty can help improve workplace political behavior.

Furthermore, employees will use politics to influence decision-making and make the current situation benefit everyone. If the organization does not have clear rules and regulations, employees will try to convince their interests. Somoye (2016) argues that mergers and acquisitions will create workplace uncertainty. During mergers and acquisitions, new management will take over the operations of the organization. Furthermore, new management has its targets, and the remaining senior employees may refuse to follow the new management. New management can use power or authority to influence old employees. Ene (2014) mainly focuses on the factors that influence organizational politics and workplace politics implications.

Workplace politics is caused by differences in goals between personal and organizational goals (Ene, 2014). Employees need to work according to rules and regulations to achieve their personal goals. If there are no clear rules, employees will start to persuade their interests, and sometimes this will affect the achievement of organizational goals. Besides, there are many units in the organization, and each unit has its own goals to achieve. They are not aware of the interdependent relationships between units for the organization to be successful.

Besides, they always try to protect themselves and achieve their targets despite harming others. For example, suppose the accounting unit wants to show high profits this year; they will try to persuade management to cut other units' budgets. It is difficult for organizations to achieve goals if there are too many personal goals. Organizational management will engage in politics to help the organization achieve its goals. Organizational politics are not always bad as sometimes; it helps solve the problem. Research by Ferris et al. (1989) suggests that environmental ambiguity will help create political behavior. If there is a common goal among employees, then workplace politics will diminish.

Hway (2018) found that the negative relationship between objective ambiguity and office politics was insignificant. The results show that most respondents agree that their roles and jobs are clear, so workplace politics is low. Environmental uncertainty helps create environmental politics. Objectives that are not clear have a positive relationship with office politics. Hway (2018) suggests organizations that create awareness about the organization's role and goals so that employees can work to achieve them.

It is essential for management to align individual goals with organizational goals. This goal is to make sure that everyone is working towards the same goal. Employees are less likely to be influenced by office politics if they share the organization's same values and goals. There are suggestions for organizations to prepare employee job descriptions in manuals. In this case, employees can have a clearer picture of what is expected of them. There is a need to formalize organizational policies and procedures to reduce objectives and job uncertainty.

Budget allocation. The second factor discussed is budget allocation. The competition will increase when resources are scarce (Kacmar \& Carlson, 1997). Every organization has a sustainable competitive advantage to be able to compete in the market. Competitive advantage can include the organization's resources and capabilities and can be divided into physical resources, organizational resources, and human resources (David, 2011). Physical assets include factories and machinery, furniture and fittings, also computers. Human resources include employees of the organization, and these employees have a lot of experience, intelligence, and capabilities. Organizational resources include goodwill, copyright, intellectual property, and more.

If the organization has unlimited resources, there is no need to allocate resources. In this study, the main focus is on corporate funds. If the organization's cash is limited, it needs 
to go through an allocation process. The allocation process is when most unit leaders and top management decide how much to allocate to each unit. Sharma \& Gautam (2014) have different interpretations of scarce resources where they suggest promotion, power, a position as scarce resources.

Eniola, lyabo, Adeshina, and Olajide's (2015) research emphasizes the causes and implications of political behavior. Therefore, there is a need to place these resources, thereby increasing political behavior. If the organization has limited resources, then political behavior will also increase. The community feels that the distribution of these resources is uneven in the organization and tends to be involved in political behavior (Sharma \& Gautam, 2014). Sonaike (2013) argues that organizational resources are limited, and each unit requires resources to run its unit. Every organization requires different resources because of their respective nature.

Hway (2018) found a positive relationship between budget allocation and office politics. Employees agree that their management needs to keep sufficient information about budget lags in the unit, and only management will know. There may be some information that management is withholding because the budget is unclear and can be questioned by everyone in the organization. Besides, employees agree that management has a way of knowing there is slack in the budget. The leadership can manage the budget by loosening the policy a little to reach the budget safely. This behavior can also be a political behavior.

To minimize political behavior, organizations can establish clear guidelines for budget allocations (Hway, 2018). If there are clear guidelines for budgeting, then employees can act reasonably and should follow these guidelines. However, it can happen that if employees use too much guidance, it may increase disagreement within the leadership. It is essential that the guidelines are shared among executives so that everyone has the same vision and mindset (Olorunleke, 2015). Besides, organizations can promote open communication and will encourage everyone to share their opinion, and no information is hidden, especially in the budget allocation process. Furthermore, it will also create transparency among coworkers as everyone is involved in budgeting.

However, every organization needs funds to maintain its operational activities. Corporate funds can be considered a scarce resource. During the budget allocation, these leaders will use their power to influence budget allocations. Power and interaction in budget allocation act as political behavior.

Decision making. Kacmar \& Carlson (1997) argues that if there is much uncertainty in decision-making, it will increase political behavior. Every leader wants to make rational decisions during the meeting. A rational decision means the optimal choice to maximize its value and involves six steps. The six steps will include defining the problem, identify decision criteria, allocating weights to criteria, developing alternatives, evaluating alternatives, and selecting the best alternative (Robbins \& Judge, 2013). Nobody makes decisions based on six steps. Usually, decisions will be made based on fair judgment (Robbins \& Judge, 2013). Because of the obstacles, people generally decide based on judgments and institutions. Once the problem is determined, the community starts looking for a solution. When a solution solves a problem with current solutions, that society will stop finding optimal solutions.

Besides that, time and cost are also constraining factors in finding optimal solutions. Another factor that also influences rational decisions is that the leader will decide based on his experience. Robbins and Judge (2013) stated that this decision-making was irrational. However, they have further explained that following the experience does not mean it is wrong. There is a need for the leadership to decide during the meeting. Rational decisionmaking involves six steps which should be discussed in the previous section of the literature. If the leader uses six steps to decide, it will be expensive and take longer.

In the business world, leaders need to make decisions quickly; otherwise, the opportunity will be lost. If there are few coalitions in the group, the coalition group will tentatively try to influence the leadership to choose a favorable decision (Kinicki, 2008; Sonaike, 2013). Witt (1992) suggests that some leaders may not want to discuss work with their subordinates because they want to keep information from employees. Sometimes, they want employees to comply without questioning them. In this case, they tend to hold power 
and authority. One researcher mentions power and inter-relationship as political traits (Elbanna, 2006).

Hway (2018) found a negative relationship between decision-making and workplace politics. Most employees will discuss their concerns with their superiors in moderation. There are still few options for employees to choose from; even though their superiors allow them to voice their opinions, Employers may want to control employee behavior and follow their directions. Some employees agree that they do not have many discussions to be ahead of their boss. If an employee does not discuss the problem with his superior, it means that the boss tends to hold authority and wants his subordinates to have much information.

There is a need for organizations to implement rational decision-making procedures to minimize superiors from holding authority. Sometimes it is challenging to implement rational decision-making. Rational decision-making involves six steps, and this has been discussed in the previous chapter (Robbins \& Judge, 2013). Organizations can expand or ensure that there are simple and straightforward guidelines so that everyone can follow them. This process of developing this guide may need to involve someone with experience in the organization.

The organization also has to raise awareness about the guidelines so that every employee has the same idea. If an organization uses past experiences, it is not a rational decision, but that does not mean it is wrong. Sometimes, an experienced manager is still needed to solve problems (Robbins \& Judge, 2013). Once a decision has been made, there is also a need to examine the consequences of decision-making to evaluate whether the decisions made were right or not (Pfeffer, 1992). Also, managers must decide which decisions to choose and resolve the consequences of decision-making (Pfeffer, 1992).

Most of the time, leaders make decisions based on their experience. They will try to explain the decisions' results to their subordinates and convince them that their decisions are correct. During the discussion, several alternatives can be selected. Assuming there are few coalitions in the group and each group disagrees with each other. The leader will be the last person to choose an alternative, and this alternative will be implemented. If the coalition benefits the leader, the leader will choose alternatives that benefit the coalition.

Salary and promotion. Salary and promotion are reward systems to increase employee commitment (Markham, Harlan, \& Hackett, 1987; Ruderman \& Ohlott, 1994). The purpose of this promotion is to retain talents and motivate them to work towards goals. One study states that promotion changes a person's status at work and comes with an increased salary, power, and work scope (Ruderman \& Ohlott, 1994).

Throughout the year, employees may feel bored with their current scope of work. Promotions and salaries not only reward employees but also develop employee abilities. Usually, the superior will be in charge of the subordinate's promotions. Before employees are promoted, there is a performance evaluation process. Employee's past performance evaluates performance. Sometimes, promotions can also come from outside the organization.

Organizations can post positions to outsiders and recruit outsiders to take over the position (Ruderman \& Ohlott, 1994). There are several advantages to promoting internal employees. Employees will think that the organization helps them develop careers. However, there are several shortcomings, namely the absence of new knowledge that has entered. If employees come from outside, there will be changes in the organization because of the new leadership style. The disadvantage is that existing employees may have resistance to the new leadership.

For payments and promotions, every organization has a payment and promotion policy. If employees feel unfair about rewards compared to employees' involvement in political behavior, they will engage in that behavior. Employees in organizations work hard to be promoted to the management level. However, if the employee does not like their boss, they are less likely to be promoted to the next level. To get a promotion, employees will start doing things their superiors like to agree on the superior's decision making in meetings and help their superiors in administrative matters (Sonaike, 2013). 
Khan and Hussain's (2014) research mainly focuses on the political perceptions of university organizations. Researchers state a strong relationship between organizational clusters at the university and employee survival. The second indicator is employee satisfaction about salary and promotions.

Perceptions of organizational politics have three main areas: General Political Behavior, Going Forward, and Salary and Promotion. These three concepts have been discussed above. The results showed a significant relationship between strong groups and organizational employees' survival for the first indicator. Furthermore, the researcher states that politics occurs in universities, even though this is a place of academic learning (Khan \& Hussain, 2014). If lecturers and education personnel do not join more influential groups, they will quickly lose their jobs or positions. The second indicator shows a significant relationship between salary and organizational promotion with lecturers and teaching staff satisfaction. Researchers suggest that organizations hire consultants to analyze their organizational, political behavior to improve the organization's work environment. In conclusion, university employees are no different. Organizations should try to understand why political behavior increases (Khan \& Hussain, 2014).

Besides, there is a need to fine-tune their human resource policies to improve the working environment (Khan \& Hussain, 2014). Few employees apply for promotions. One employee felt that he might have few chances to get a promotion, so he began to influence his boss. When they get promoted, other people's employees will start complaining behind their backs. During the promotion period, political behavior will also increase. One researcher suggested that employees engage in political behavior if they use their power to influence others (Robbins, 2003; Sonaike, 2013). Somoye (2016) argues that if the organization does not have a standard policy for payroll and promotion, the leader cannot distinguish who has a good performance. Usually, they will promote their favorite subordinates.

Hway (2018) found a negative relationship between salary and promotion to office politics, and the results were significant. The majority of employees are dissatisfied with the amount of salary and promotions they get. Employees prefer to remain silent or not have time to discuss their superiors about salary and promotions. Furthermore, the increase in political behavior is also caused by superiors who tend to control employees. Usually, the performance appraisal evaluation will be carried out by excel. Sometimes subjective because it is based on the opinion of one person. This opinion will increase employee perceptions of injustice.

Sun and Xia's research (2018) suggests a relationship between office politics and employee silence. Even though these employees fit into the organization, they will still do it even though they feel disappointed with the organization because they are not satisfied with the organization. Thus, they continue to be silent about the problems they face (Sun \& Xia, 2018). Cacciattolo (2013) suggests that one issue that cannot be ignored is jealousy among coworkers. Barridge and Kringelbach (2008) suggest that it is difficult for employees to be satisfied with their salaries if they know that their colleagues' salaries are higher than theirs. Employees in the Organization feel jealous because their peers have higher salaries compared to them. Sometimes, employees may need to realize that colleagues have more competence and abilities. Also, their coworkers may have performed well, so they were promoted faster than others. The organization needs to issue guidelines on salaries and promotions.

Besides, it is also to encourage the organization to participate in the performance appraisal process. This guideline allows employees to voice their opinion and the job issues they face during their supervisor's performance appraisal interview. Additionally, the employer can use this time to explain to employees the decisions made on their promotion. Furthermore, superiors must avoid favoritism in the department and act reasonably with each employee and help create the perception that employees are doing great work rather than pleasing the boss. Apart from that, it will also help employees focus more on their work and increase office efficiency.

Power. The final factor discussed is the decisive influence in organizations. Although power cannot be seen, it can influence others' desires (Robbins \& Judge, 2013). There is a 
greater dependence on the power of individual people. Therefore, there are two types of power, namely personal power and formal power.

Personal power means that there are specificities in personal characteristics and can influence others (Robbins \& Judge, 2013). There are several types of personal power which are expert power and reference power. Expert power means that the person is an expert in a particular field. Everyone relies on personal opinion to make decisions. For example, a doctor's opinion in making decisions then the patient will follow the instruction. The power of reference means that the person has some unique characteristics. People admire specific individuals, then that individual influences person. Sometimes, people may want to please specific individuals. Leaders do not always hold reference power; it could be their subordinate.

Formal power is also defined as legitimate power and authority granted by the organization to certain people (Robbins \& Judge, 2013). Examples of power can be coercive power, reward power, legitimate power, coercive power, which means having the power to threaten employees. For example, leaders can dismiss their subordinates if they are not performing well. The power of appreciation means that the person has the power to reward his subordinates. For example, the leader has the power to reward, such as increasing employee salaries, bonuses, and others. Legitimate power means the person has formal authority. For example, the managing director will be at the top of the organization and have legitimate authority.

Most employees want to gain power in the organization. There are three types of people involved in power activities: small business owners, top management, and critical people in the Organization (Somoye, 2016). Small business owners need to make their own decisions because they own the business. Apart from that, they are also entitled to promote these employees. The second is the company's top management because they need to oversee its activities and make decisions. The third is the organization's key person; their input is essential for the company in making decisions.

Companies that change rapidly are likely to face power and political problems to streamline organizational processes (Somoye, 2016). Power always comes from position, and some come from the person. During the meeting, some subordinates may disagree with the leadership's decision, and each subordinate has his ideas. Thus, leaders will try to use power to influence them to show that their decisions are correct. Sometimes, they will even use their skills to explain the outcome of the decision.

Furthermore, if subordinates have a high dependence on their leaders, then the leadership has power over their employees (Robbins \& Judge, 2013). For example, leaders control employee salaries and promotions. This control decision is essential for employees because they need it to make a living. Employees will work hard and try to please their boss. Furthermore, they will even support whatever decisions their leader makes.

Some individuals do not have the legal power, but they influence others because of their unique personal characteristics. The influence of power can sometimes be positive and not necessarily all negative. For positive results, the leader uses the power to delegate the work of his subordinates. Furthermore, they also use power to create subordinate opportunities. For negative results, leaders use their power to monitor employees closely. Some leaders also use power to achieve their benefits (Somoye, 2016). Besides, most leaders spend most of their time managing their power to influence others to achieve company goals (Somoye, 2016).

Hway (2018) found a negative relationship between power and office politics. Employees perceive workplace politics as a bad thing. So, they choose to obey their boss rather than use tactics to influence their boss or colleagues. Power and politics cannot be separated. Power can be divided into many types, namely legitimate, reward, coercive, personal power, and others. Leaders need to know how to use different types of decisive influence in the right situation. Managers also need to avoid abuse of power; it can affect the relationship between subordinates. One writer suggests that superiors can use office politics for harmony and ensure balance in the company (Daud, Isa, Nor, \& Zainol, 2013). Hence, it has a low level of office politics. 
Job Dissatisfaction. Job satisfaction is about how employees think and feel about their jobs (Javed, Balouch, \& Hassan, 2014; Spector, 1997). Besides, job satisfaction is the primary concern of every organization. The organizational contribution will increase if employee job satisfaction increases (Javed, Balouch, \& Hassan, 2014). Mishra (2013) states that job satisfaction has three aspects: job factors, individual factors, and organizational factors. The first factor is work factors, including age, gender, and employee education. Individual factors include work, skills, and employee responsibilities. The final factor is the element controlled by top management: salary, raise, promotion, and work environment.

The opposite of job satisfaction is job dissatisfaction. Job dissatisfaction arises from bad experiences in work or current job opportunities (Talukder, Talukder, \& Alam, 2014). Job dissatisfaction can lead to employee turnover or absence. Organizational politics can affect the relationship between employers and workers and pollute the workplace's social environment (Cropanzano et al., 1997; Salam, 2016). Ferris and Kacmar's (1992) research suggests there are few results for workplace politics. Some employees may resign from the organization if they do not wish to participate in workplace politics.

There are two types of withdrawal in the workplace: absence and resignation (Ferris \& Kacmar, 1992). Workplace politics are stressful for employees. Thus employees will lose interest in their working time (Cacciattolo, 2013). Also, employees cannot concentrate on their work (Eniola, lyabo, Adeshina, \& Olajide, 2015). Because employees are not happy with the current situation, it may have reduced employee satisfaction (Hassan, Vina, \& Ithnin, 2017). If the employee's job dissatisfaction increases, there will be low performance.

Hway (2018) found a positive relationship between job dissatisfaction and workplace politics. Employees who are not happy with the current job situation are job dissatisfied. Dissatisfaction also arises when their workplaces are conflicting and have many procedures. Hence, workplace politics have a direct influence on job dissatisfaction, and the results are also significant. Shahani, Baloch, Jhatial, and Halepota (2017) suggest that organizational justice can minimize political behavior.

Three types of organizations are predominantly involved in workplace politics: workgroups, interest groups, and coalitions. These three groups have their own goals and benefits to be achieved. Because of this, they are always involved in political behavior to achieve their targets. There are six factors selected and discussed which are related to political behavior.

The first factor is the unclear objectives of the organization. The argument in this factor is that every individual has a goal to be achieved. Their goals differ from organizational goals. If there are no clear rules, they will try to achieve their goals regardless of organizational goals.

The second factor is the organization's budget allocation. Organizational resources are limited, and every unit in the organization competes for resources; thus, they will become involved in political behavior. If the organizational resources are sufficient, then political behavior in the organization will decrease.

The third factor is organizational decision-making. In these meetings, employees of the organization will tend to influence the decision-making process so that the decisions taken are profitable. They also want to tell everyone that their ideas are essential for decisionmaking (Sharma \& Gautam, 2014).

The fourth factor is salary and promotion. Organizations need to have clear performance evaluation criteria. Employees need to work according to rules and regulations to achieve organizational goals and objectives. If there is no common goal, the supervisor will promote the employee into their circle of trust.

The last factor is power. Every individual in the organization wants power. Power can influence others, and others will follow personal instructions. Some leaders have power, but this power comes from their position, which is called formal power. Even though some people do not have this position, they have personal characteristics that can influence other people, called personal power. Individuals in influential organizations like to get involved in politics because they can lay off an employee. 
The five indicators have been formed through the discussion above, and there is a relationship with political behavior. The last indicator that is formed is to examine the relationship between workplace politics and job dissatisfaction. Job dissatisfaction impacts workplace politics and is not the same as the five factors that influence workplace politics.

Job satisfaction is how employees feel about their job (Javed, Balouch, \& Hassan, 2014; Spector, 1997). Julius, Ojiabo, and Alagah (2017) suggest a negative relationship between organizational politics. A high level of politics will lead to low job satisfaction because employees perceive injustice and injustice. Workplace politics can be stressful for employees. Furthermore, the employee will have negative thoughts during working time. Hassan, Vina, and Ithnin (2017) suggest that employee satisfaction will also decrease if they are not satisfied with the current environment.

\section{CONCLUSION}

Politics means government activities consisting of the involvement of parties and relations between countries. Three types of organizations are predominantly involved in workplace politics: workgroups, interest groups, and coalitions. These three groups have their own goals and benefits to be achieved. Workplace politics also have several consequences: employee resignation from the organization or employee absence. Because of this, they are always involved in political behavior to achieve their targets. Several indicators are formed through the above discussion. There are relationships with political behavior; the five indicators are unclear objectives, budget allocation, decision making, salary and promotion, power, and job dissatisfaction. The last indicator that is formed is to examine the relationship between workplace politics and job dissatisfaction. Job dissatisfaction impacts workplace politics and is not the same as the five factors that influence workplace politics.

\section{REFERENCES}

1. Buchanan, D. (2008). You stab my back; I will stab yours: management experience and perceptions. British Journal of Management Vol. 19 No. 1, 49-64.

2. Cacciattolo, K. (2013). Organizational Politics And Their Effect On Workplace Learning. European Scientific Journal, 198-211.

3. Cropanzano, RS, Howes, JC, Grandey, AA, \& Toth., P. (1997). The relationship of organizational politics and support to work behaviors, attitudes, and stress. Journal of Organisational Behavior, 18, 159-180.

4. Daud, Z., Isa, MF, Nor, WS, \& Zainol, Z. (2013). Office Politics: The Reduction of Employees' Need for Power. International Journal of Business and Social Science Vol. 4 No. 11, $29-35$.

5. David, FR (2011). The Resource-Based View (RBV). In Strategic Management Concepts and cases 13th ed (pp. 1-694). New Jersey: Pearson Education, Inc.

6. Elbanna, S. (2006). Strategic decision making. International Journal of Management Reviews Volume 8 Issue 1, 1-20.

7. Ene, OC (2014). Assessment of Factors Responsible for Organizational Politics and Its Implications in the Workplace. Journal of Educational Policy and Entrepreneurial Research (JEPER) Vol.1, N0.2, 94-98.

8. Eniola, SO, Iyabo, AS, Adeshina, AT, \& Olajide, AO (2015). Organizational Politics Causes and Effects On Organisation And Employees. International Journal of Business, Economics, and Management, 204-208.

9. Ferris, GR, \& Kacmar, KM (1992). Perceptions of Organization Politics. Journal of management, 93-116.

10. Ferris, GR, Russ, GS, \& Fandt, PM (1989). Politics in organizations. In RA Giacalone \& P. Rosenfeld (Eds.) Impression Management in the organization (pp. 143-170). Hillsdale, NJ: Erlbaum. 
11. Hassan, H., Vina, TM, \& Ithnin, NS (2017). Perceived Organisational Politics and Job Satisfaction: The Role Of Personality As Moderator. Scientific Journal of Logistics, 13 (4), 479-493.

12. Hway, AS (2018). An Investigation into The Determinants of Office Politics. Universitas Tuanku Abdul Rahman

13. Javed, M., Balouch, R., \& Hassan, F. (2014). Determinants of Job Satisfaction and its Impact on Employee Performance and Turnover Intentions. International Journal of Learning \& Development, 120-140.

14. Julius, NT, Ojiabo, U., \& Alagah, AD (2017). Organizational Politics And Employee's Job Satisfaction In The Health Sector Of Rivers State. International Journal of Advanced Academic Research, 88 - 106.

15. Kacmar, KM, \& Carlson, DS (1997). Further Validation of the Perceptions of the Politics Scale (POPS): A Multiple Sample Investigation. Journal of Management, 627-658.

16. Kacmar, KM, \& Ferris, GR (1991). Perceptions of Organisational Politics Scale (POPS): Development and Construct Validation. Educational and Psychological Measurement, 193-205.

17. Khan, MA, \& Hussain, N. (2014). The Analysis of the Perception of Organisational Politics among University Faculty. International Conference on Social Sciences and Humanities, 569-577.

18. Mekasha, KM (2015). Assessment of Budget Preparation and Utilization: Case of Addis Ababa City Administration Health Bureau. 1-74.

19. Miller, B., Rutherford, M., \& Kolodinsky, R. (2008). Outcomes associated with perceptions of organizational politics: a meta-analysis. Journal of Business \& Psychology, Vol. 22 No. 3, 209-222.

20. Mishra, PK (2013). Job Satisfaction. Journal Of Humanities And Social Science Volume 14 , Issue 5, 45-54.

21. Nasurdin, AM, Ahmad, NH, \& Razalli, AA (2014). Politics, Justice, Stress, and Deviant Behaviour In Organisations: An Empirical Analysis. International Journal of Business and Society, Vol. 15 No. 2, 235 - 254.

22. Olorunleke, G. (2015). Effect of Organizational Politics on Organizational Goals and Objectives. International Journal of Academic Research in Economics and Management Sciences Vol. 4, No. 3, 59-70.

23. Olson, B., Bao, Y., \& Parayitam, S. (2014). Political behavior, trustworthiness, job satisfaction, and commitment: An empirical study. Chinese Management Studies, 354-374.

24. Omisore, BO, \& Nweke, AN (2014). The Influence of Power and Politics in Organizations (Part 1). International Journal of Academic Research in Business and Social Sciences Vol. 4, No. 7, 164 - 183.

25. Pfeffer, J. (1992). Understanding Power. In Managing with Power (pp. 29-50). Boston: Harvard Business School Press.

26. Rahman, MN, Doroodian, M., Kamarulzaman, Y., \& Muhamad, N. (2015). Designing and Validating a Model for Measuring Sustainability of Overall Innovation Capability of Small and Medium-Sized Enterprises. Open Access sustainability ISSN 2071-1050, 537-562.

27. Robbins, SP, \& Judge, TA (2013). Power and politics. In Organisation behavior (Fifteen editions) (pp. 412-440). United States of American: Pearson Education, Inc.

28. Ruderman, MN, \& Ohlott, PJ (1994). The realities of management promotion. Greenboro,

29. North Carolina: Center for Creative Leadership.

30. Salam, MA (2016). Relationship between Perceived Organizational Politics, Supportive Organizational Climate and Job Satisfaction in Thai Higher Education Sector. Mediterranean Journal of Social Sciences Vol 7 No 5, 309-407.

31. Shahani, N. u., Baloch, MN, Jhatial, AA, \& Halepota, JA (2017). Perception of Politics (POP) And Mediating Role of Justice On Job Satisfaction And Work-Related Burnout Among Administrative And Academic Staff In Universities Of Sindh. European Journal of Business and Social Sciences, Vol. 6, No. 02, 207 - 218. 
32. Sharma, S., \& Gautam, O. (2014). An Empirical Analysis on Office Politics in Indian Organisations. Human Resource Reflection 1(3), 86 - 92.

33. Somoye, KG (2016). The Effects of Power and Politics in Modern Organizations and its Impact on Workers' Productivity. International Journal of Academic Research in Business and Social Sciences Vol. 6, No. 11, 566-574.

34. Sonaike, K. (2013). Revisiting The Good And Bad Sides Of Organizational Politics. Journal of Business \& Economics Research, 197-202.

35. Spector, PE (1997). Job satisfaction: Application, assessment, causes, and consequences. Thousand Oaks: CA: Sage.

36. Sun, Y. w., \& Xia, H. s. (2018). Research on Perceptions of Organizational Politics and Its Influence on Employee Silence. Open Journal of Business and Management, 250-264.

37. Talukder, MS, Talukder, MF, \& Alam, MJ (2014). Job Dissatisfaction and Turnover: Bangladesh Perspective. European Journal of Business and Management Vol.6, No.17, 117-125.

38. Witt, LA (1992). Organizational Politics, Participation in Decision-Making, and Job Satisfaction. Virginia: National Technical Information. 